\title{
SDS-PAGE Analysis of Soluble Proteins in Reconstituted Milk Exposed to Different Heat Treatments
}

\author{
Snezana Jovanovic*, Miroljub Barac, Ognjen Macej, Tanja Vucic, Caslav Lacnjevac \\ Institute of Food Technology and Biochemistry, Faculty of Agriculture, University of Belgrade, 11081 \\ Belgrade-Zemun, Serbia
}

Snezana Jovanovic, e-mail: snezanaj@agrifaculty.bg.ac.yu, Miroljub Barac, e-mail: baracm@agrifaculty.bg.ac.yu, Ognjen Macej, e-mail: mleko@ agrifaculty.bg.ac.yu, Tanja Vucic, email: tvucic@agrifaculty.bg.ac.yu, Caslav Lacnjevac, e-mail: lcaja@agrifaculty.bg.ac.yu

*Author to whom correspondence should be addressed. E-mail: snezanaj@agrifaculty.bg.ac.yu Received:26 February 2007 / Accepted:15 March 2007 / Published: 23 March 2007

\begin{abstract}
This paper deals with the investigation of the impact of the heat treatment of reconstituted skim milk conducted at different temperatures, and the adding of demineralized whey on the protein solubility, soluble protein composition and interactions involved between proteins in a chemical complex. Commercial skim milk has been reconstituted and heat treated at $75^{\circ} \mathrm{C}, 85^{\circ} \mathrm{C}$ and $90^{\circ} \mathrm{C}$ for 20 minutes. Demineralized whey has been added in concentrations of $0.5 \%, 1.0$ and $2.0 \%$. The soluble protein composition has been determined by the polyacrilamide gel electrophoresis (SDS-PAGE) and by the densitometric analysis. Due to the different changes occurred during treatments at different temperatures, proteins of heat-treated samples containing added demineralized whey have had significantly different solubility. At lower temperatures $\left(75^{\circ} \mathrm{C}\right.$ and $\left.85^{\circ} \mathrm{C}\right)$ the adding of demineralized whey decreased the protein solubility by $5.28 \%-26.41 \%$, while the addition of demineralized whey performed at $90^{\circ} \mathrm{C}$ increased the soluble protein content by $5.61 \%$ $28.89 \%$. Heat treatments, as well as the addition of demineralized whey, have induced high molecular weight complex formation. $\beta-\mathrm{Lg}, \alpha-\mathrm{La}$ and $\kappa$-casein are involved in high molecular weight complexes. The disulfide interactions between denatured molecules of these proteins are mostly responsible for the formation of coaggregates. The level of their interactions and the soluble protein composition are determined by the degree of temperature.
\end{abstract}

Keywords: casein, whey proteins, heat treatment, disulfide interaction. 


\section{Introduction}

The heat treatment of milk during commercial processing operations results in a number of physicochemical changes in the milk constituents. Significant changes occurring upon heating milk above 60 ${ }^{\circ} \mathrm{C}$ include the denaturation of whey proteins, the interactions between the denatured whey proteins and the casein micelles, the conversion of soluble calcium, magnesium and phosphate to the colloidal state $[1,2,3]$. The level of these changes depends on both the temperature and length of heat treatment.

Casein is the major protein component of milk which represents 75-80\% of all milk proteins [4]. Due to its complex composition, casein belongs to the group of phospho-glycoproteins [4, 5]. Also, casein belongs to the group of heat-stable proteins, because it does not coagulate when subjected to a high heat treatment.

The whey protein fraction represents about $18-20 \%$ out of total of milk proteins. This fraction contains four major proteins: $\beta$-lactoglobulin ( $\beta$-Lg), $\alpha$-lactalbumin $(\alpha$-La), blood serum protein (BSA) and immunoglobulin (Ig). These proteins represent 50\%, 20\%, 10\% and $10 \%$ of whey protein fraction, respectively. Besides the major proteins, the whey fraction contains numerous minor proteins such as proteose peptone fraction (PP), osteopontin, vitamin binding proteins, lactoferrin and about sixty indigenous enzymes. Whey proteins are heat-labile proteins. According to Donovan and Mullhvill [6], heat decreases their stability in the following order: $\mathrm{PP}>\alpha-\mathrm{La}>\beta-\mathrm{Lg}>\mathrm{BSA}>\mathrm{Ig}$. When whey proteins are exposed to high temperatures, they irreversibly denature and coagulate. The denaturation of whey proteins starts at $65^{\circ} \mathrm{C}$, but it mostly occurs during milk heating at temperatures above $80^{\circ} \mathrm{C}$. The degree of whey protein denaturation is frequently determined by the degree of $\beta$-Lg denaturation, since it represents about $50 \%$ of all whey proteins [7].

During heat treatment, milk proteins may interact and form chemical complexes. The protein complex between $\alpha$-La and $\beta$-Lg, $\alpha$-La and $\kappa$-casein, as well as the complex between $\beta$-Lg and $\kappa$-casein develops. In literature, the chemical complexes between milk proteins are known as co-aggregates of milk proteins.

In recent literature, the two theories explain the mechanism of the co-aggregate formation. According to the first one, it is a two step process. In the first step, the denatured whey proteins aggregate at a ratio dependent on the initial individual whey protein concentrations. These complexes subsequently associate with the casein micelles during the prolonged heating [8]. The major interaction appears to involve the thiol-disulfide exchange reactions between the denatured $\beta$-Lg and $\kappa$-casein at the micelle surface. The second theory by Mottar et al. [9] suggests that at high temperatures $\beta$-Lg first denatures, and then interacts with casein. At a higher temperature $\left(90^{\circ} \mathrm{C} / 10 \mathrm{~min}\right) \alpha$-La denatures and binds with filaments of $\beta$-Lg.

Several authors $[8,10,11]$ have investigated the effect of different processing factors on the coaggregates formation.

The aim of these experiments was to investigate the impact of different heat treatments, as well as the addition of demineralized whey, on the changes that occur in reconstituted skim milk. 


\section{Experimental Part}

Heat treatments. Commercial skim milk powders $(92.79 \%$ of dry matter, $0.05 \%$ of fat, $30.07 \%$ of proteins, 95.44\% solubility) have been obtained from Impaz co. (Zajecar, Serbia). The experimental skim milk samples have been prepared by reconstituting skim milk to $9 \mathrm{~g} / 100 \mathrm{~g}$ in deionized and filtered water $(0.45 \mu \mathrm{m}$ filters, Milipore Co., USA). Reconstituted skim milk samples have been left to equilibrate at $4{ }^{\circ} \mathrm{C}$ over night, and centrifuged before further treatment. Skim milk samples have been treated at $75^{\circ} \mathrm{C}, 85^{\circ} \mathrm{C}$, and $90^{\circ} \mathrm{C}$ for 20 minutes. Treated samples have been left to cool at ambient temperature and centrifuged at $3.000 \mathrm{rpm}$ for 15 minutes prior to further analysis.

Reconstituted skim milk with the demineralized whey added was prepared according to the following procedure. Skim milk was reconstituted in deionized and filtered water $(0.45 \mu \mathrm{m}$ filters, Milipore Co., USA). Samples have equilibrated at $4{ }^{\circ} \mathrm{C}$ over night, and centrifuged before the adding of the demineralized whey. Demineralized whey powder $(96.38 \%$ dry matter, $0.1 \%$ fat, $10.03 \%$ protein, $97.67 \%$ solubility) was added in concentrations of $0.5 \%, 1.0 \%$ and $2.0 \%$, equilibrated at $4{ }^{\circ} \mathrm{C}$ over night, and centrifuged at $3.000 \mathrm{rpm}$ for 15 minutes prior to further treatment. These samples were also treated at $75^{\circ} \mathrm{C}, 85^{\circ} \mathrm{C}, 90^{\circ} \mathrm{C}$ and $95^{\circ} \mathrm{C}$ for 20 minutes, cooled at ambient temperature and centrifuged at $3.000 \mathrm{rpm}$ for 15 minutes prior to further analysis.

Soluble protein content detection. The change of soluble protein content was detected by the method of Bradford [15], using bovine serum protein (BSA, Sigma, USA) as standard.

Soluble protein composition. The soluble protein composition of the treated skim milk samples was detected by the SDS-polyacrilamide gel electrophoresis (SDS-PAGE) performed according to Fling and Gregerson [16] on $12.5 \%$ and $15 \%$ slab gel. Prior to the electrophoresis, soluble proteins have been diluted to $2 \mathrm{mg} / \mathrm{cm}^{3}$ with the sample buffer ( $\mathrm{pH} 6,8$ ). Two types of diluted samples have been prepared, with and without 2-mercaptoethanol (0.05\%).2-Mercaptoethanol was used as dissociating reagent to obtain degradation of co-aggregates possibly formed by disulfide interactions. The vertical electrophoresis unit LKB-2001-100 was used in conjunction with the power supply Macrodrive 5 and Multitemp II (LKB, Sweden). Samples $\left(0.017 \mathrm{~cm}^{3}\right.$ for $12.5 \%$ and $\left.0.02 \mathrm{~cm}^{3}\right)$ were run at $50 \mathrm{~mA}$ for five hours. The gel was stained with the $0.23 \%$ solution of Coomasie Blue R-250 for 90 min., and destained in the methanol/acetic acid solution (5\% methanol, 7\% acetic acid). Destained gels have been scanned using the Scanexpress 12000 (Mustac, Germany) and analyzed with the SigmaGel for Windows version 1.1 software (Jandel Sci Corporation, USA). Detected polypeptides were identified using the standards of $\alpha$-La, $\beta$-Lg, $\kappa$-casein, $\alpha$-casein, $\beta$-casein (Sigma, USA) and the low molecular weight kit (LKB-Pharmacia, Sweden).

Each reported value is the mean value of three determinations of three replications. 


\section{Discussion}

\subsection{Protein solubility}

According to results presented (Table 1), the heat treatment and the addition of demineralized whey have different effects on the soluble protein content. The protein solubility of the heat-treated reconstituted samples with no added demineralized whey was the similar. The soluble protein content of these samples has been in the range from $20.63 \mathrm{mg} / 100 \mathrm{ml}-21.81 \mathrm{mg} / 100 \mathrm{ml}$. This indicates that the used heat treatments have no significant influence on the soluble milk protein content.

The addition of the demineralized whey (DW) had different influence on the soluble protein content of the reconstituted skim milk. Namely, the addition of the demineralized whey has reduced the soluble protein content of milk treated at $75^{\circ} \mathrm{C}$ and $85^{\circ} \mathrm{C}$ for $10.87 \%-26.41 \%$, and $5.28 \%-9.89 \%$, respectively. On the opposite, the heating of milk at $90^{\circ} \mathrm{C}$ has increased the soluble protein content from 21.21 $\mathrm{mg} / 100 \mathrm{ml}$ to $22.40 \mathrm{mg} / 100 \mathrm{ml}-27.21 \mathrm{mg} / \mathrm{ml}$ (Table 1) i.e. for $5.61 \%-28.29 \%$. These data suggest that the lower temperatures, combined with the addition of the demineralized whey, promote the formation of the insoluble high molecular weight co-aggregates, while the higher temperature $\left(90^{\circ} \mathrm{C}\right)$ causes further degradation of proteins and co-aggregates and increases their solubility.

Table 1. Soluble protein content of heat-treated reconstituted skim milk*

\begin{tabular}{|l|l|l|l|}
\hline DW $(\%)^{* *}$ & \multicolumn{4}{l|}{ Soluble proteins $(\mathrm{mg} / 100 \mathrm{ml})$} \\
\hline & $75^{\circ} \mathrm{C}$ & $85^{\circ} \mathrm{C}$ & $90{ }^{\circ} \mathrm{C}$ \\
\hline 0 & 21.81 & 20.63 & 21.21 \\
\hline 0.5 & 16.05 & 18.59 & 27.21 \\
\hline 1.0 & 19.44 & 19.54 & 25.71 \\
\hline 2 & 19.10 & 18.85 & 22.40 \\
\hline
\end{tabular}

*the mean values of three replications

**DW-demineralized whey

\subsection{Soluble proteins composition}

The SDS-PAGE profile of soluble proteins of the untreated reconstituted skim milk is shown in Fig.1, while densitometric analysis is shown in fig. 2. 


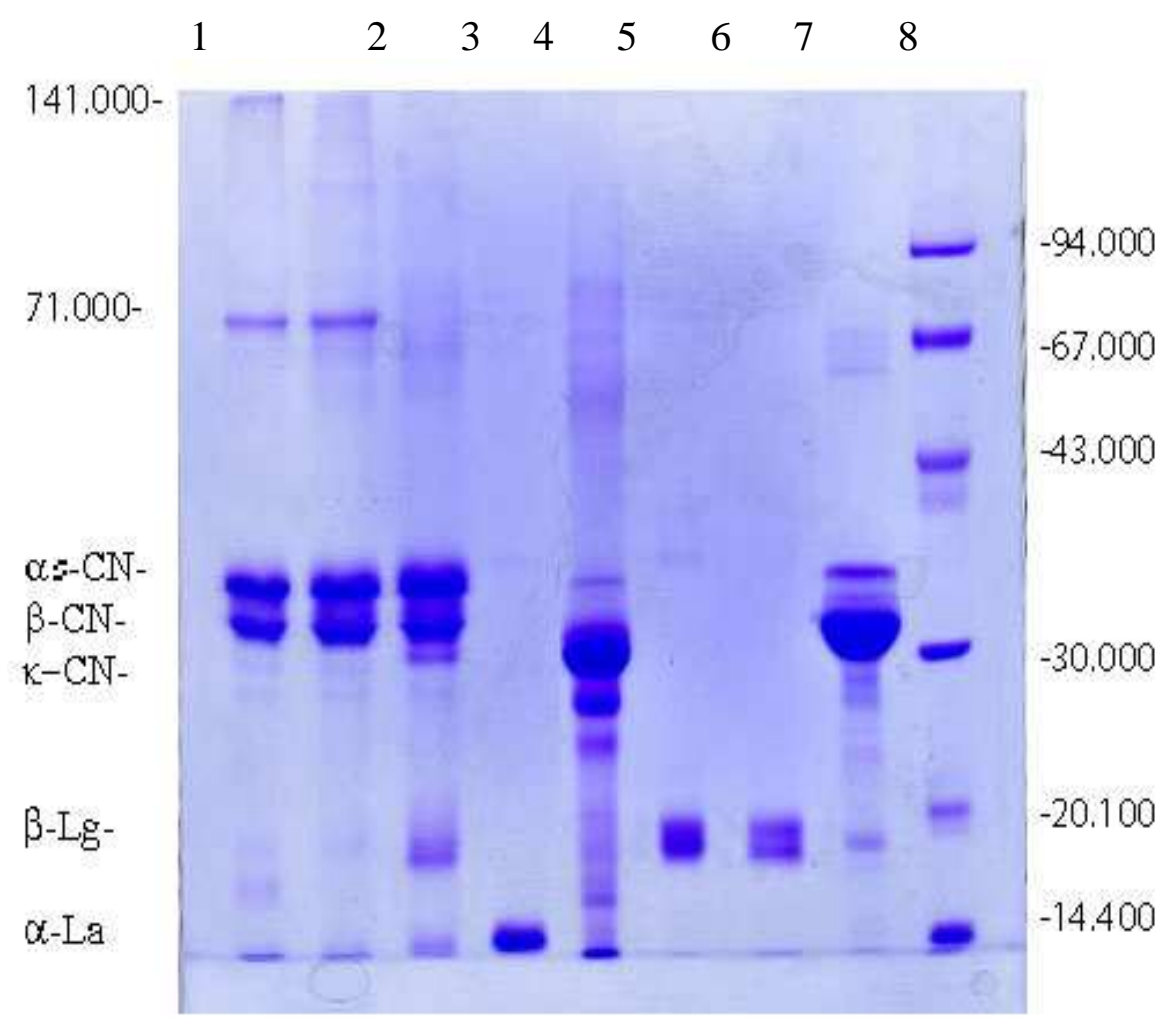

Figure 1. The SDS-PAGE pattern of the untreated reconstituted skim milk on $12.5 \%$ gel; 1.2. Reconstituted skim milk (the sample without and the sample with 2-mercaptoethanol, respectively), $3 . \alpha$ -La, 4. $\kappa$-casein, 5, 6. $\beta$-Lg, 7. $\beta$-casein, 8. Molecular weight standards. The SDS-electrophoretic profile of the soluble skim milk proteins (Fig.1, line 1) contains five major bands identified as $\alpha_{\mathrm{s}}-$ casein, $\beta$-casein, $\alpha-\mathrm{La}, 71 \mathrm{kDa}$-band, and three minor bands identified as $\beta$-Lg, $\kappa$-casein and $141 \mathrm{kDa}$ bands. According to the densitometric analysis (Fig. 2), the five major soluble components represent $83.71 \%$ of the soluble protein fraction. Furthermore, the content of the casein fraction and $\alpha-\mathrm{La}$ is $69.86 \%$ and $6.92 \%$, respectively.

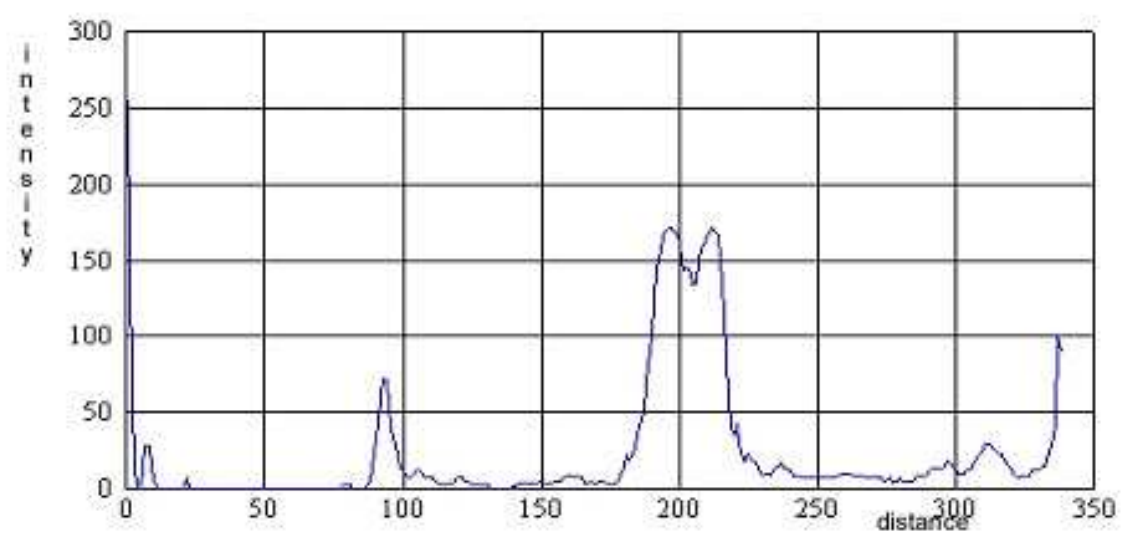

Figure 2. The densitometric analysis of the soluble proteins (without 2-mercaptoethanol) of the reconstituted skim milk. 
Contrary to $\alpha-\mathrm{La}$, the diffused bands of $\beta-\mathrm{Lg}$ and $\kappa$-casein represent only $1.84 \%$ and $1.89 \%$ out of the soluble milk proteins. According to our previous investigation [17], raw milk contains $5.27 \%$ and $22.30 \%$ of soluble $\kappa$-casein and $\beta$ - $\mathrm{Lg}$, respectively. This indicates the high level of denaturation during the skim milk preparation. Besides, this may imply that the $71 \mathrm{kDa}-, 141 \mathrm{kDa}$ - bands are the soluble chemical complexes among $\kappa$-casein, $\beta$-Lg and $\alpha-$ La.

The effect of different temperatures on the skim milk soluble proteins is shown in Fig. 3. For the reason of a better observation, the separation has been performed on $15 \%$ gels using the samples with and without 2-mercaptoethanol.

a

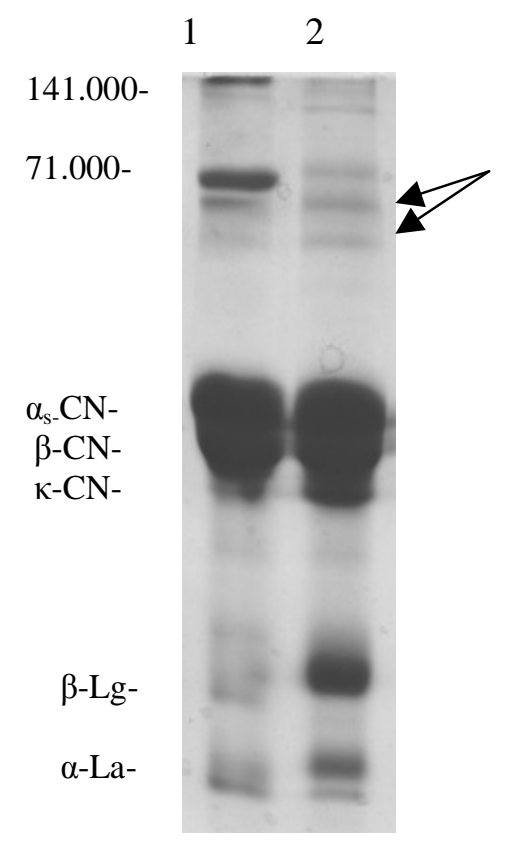

b

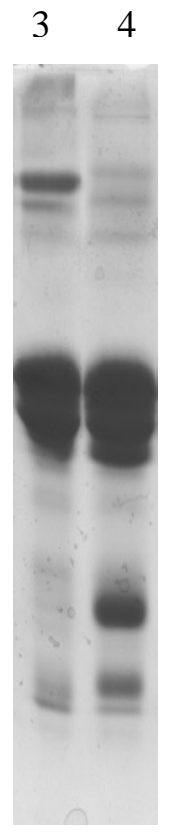

$\mathrm{c}$

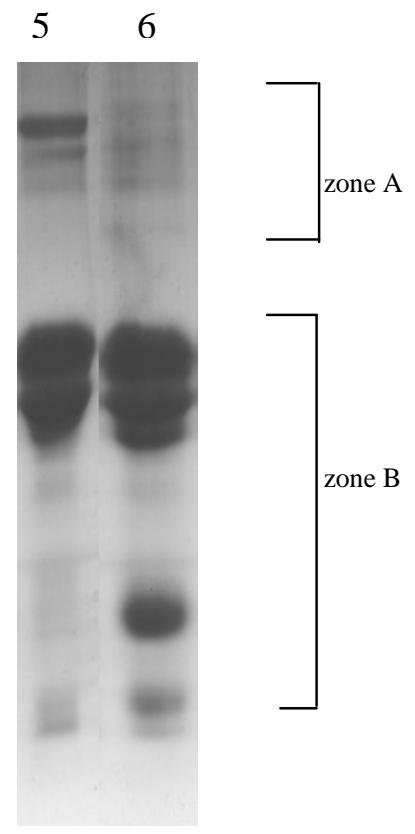

Figure 3: The SDS-electrophoretic analysis of the heat-treated samples. a. The sample treated at $75^{\circ} \mathrm{C}$ (1. without and 2.with 2-mercaptoethanol); b. The sample treated at $85^{\circ} \mathrm{C}$ (3. without and 4.with 2mercaptoethanol); c. The sample treated at $90{ }^{\circ} \mathrm{C}$ (5. without and 6. with 2-mercaptoethanol). The arrows indicate soluble $64 \mathrm{kDa}$ and $57 \mathrm{kDa}$ co-aggregates

SDS-profiles of the heat-treated samples could be divided into two zones. Zone A contains high molecular weight components (m.w. 50.000-141.000), whereas zone B corresponds to $40-10 \mathrm{kDa}-$ fractions (Fig 3). Zone B contains the most important milk proteins including $\alpha-, \beta-, \kappa-$ casein, $\beta$ - $\mathrm{Lg}$ and $\alpha$-La.

SDS-PAGE analysis clearly indicates that the chemical complexes between whey proteins and casein are formed when the reconstituted skim milk undergoes further heat treatments. Some of these complexes are soluble under experimental conditions and are characterized by the high molecular weight fractions in zone A. Depending on the degree of temperature, 5-7 high molecular weight bands have been identified in zone A. These components represent $20.36 \%-35.32 \%$ of the soluble proteins. At a lower temperature $\left(75^{\circ} \mathrm{C}\right)$, two dominant complexes characterized by m.w. of $141 \mathrm{kDa}$ and 71 $\mathrm{kDa}$ have been formed. These complexes represent $3.63 \%$ and $9.22 \%$ of the soluble proteins, 
respectively. At higher temperatures $\left(85^{\circ} \mathrm{C}, 90^{\circ} \mathrm{C}\right), 141 \mathrm{kDa}$-band has disappeared almost completely and has been observed as a diffused zone (Figure 3b, 3c). Contrarily, $71 \mathrm{kDa}-\mathrm{band}$ is more stable and represents $8.54 \%-10.35 \%$ of the soluble proteins.

1

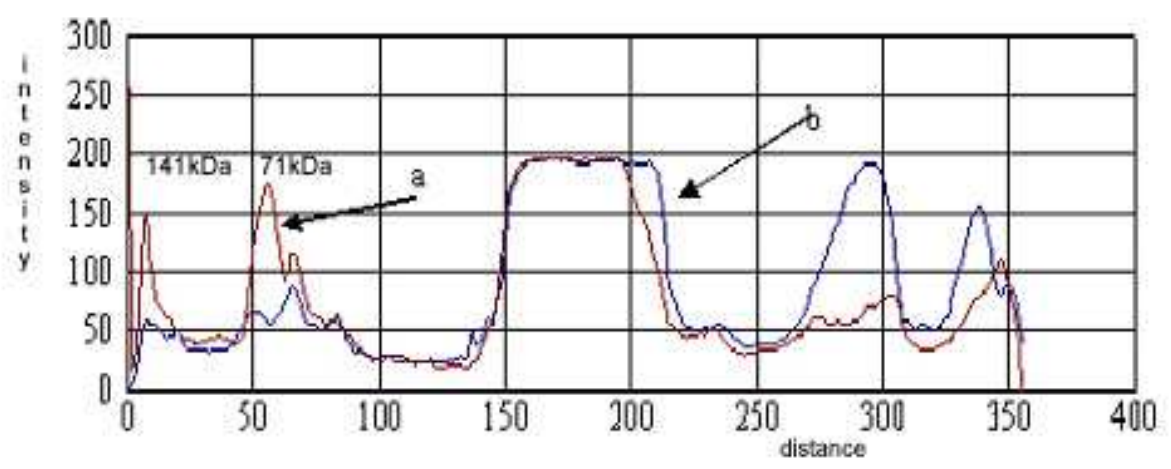

2

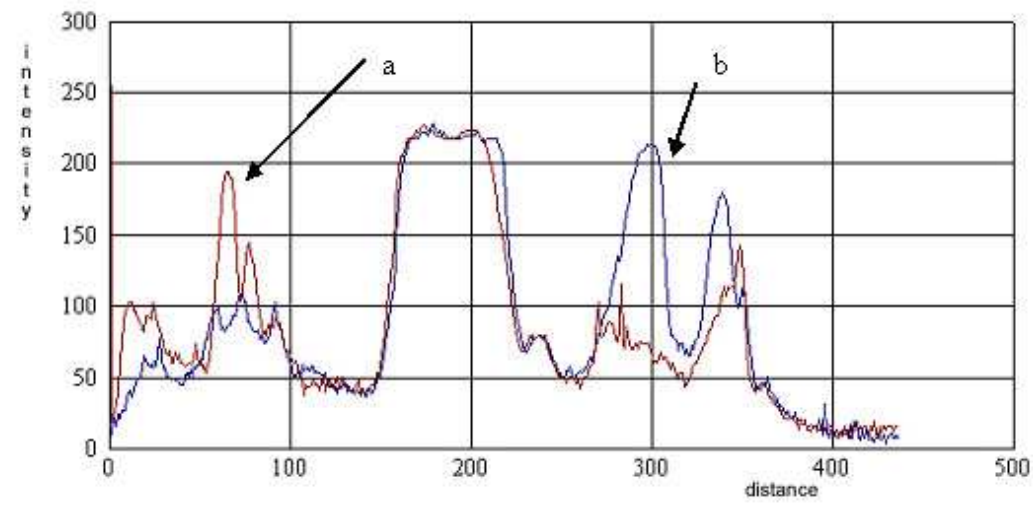

3

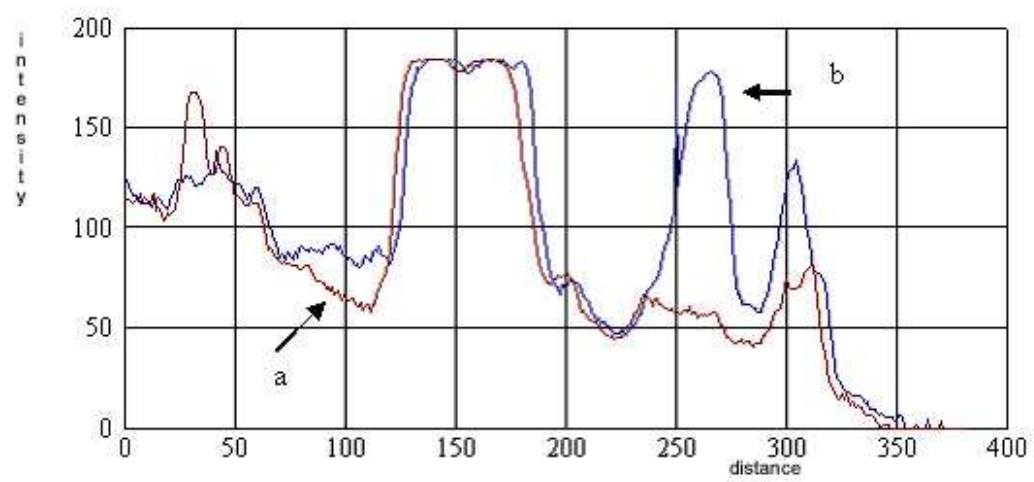

Figure 4. The comparative densitometric analysis of the soluble reconstituted skim milk proteins treated at (1) $75^{\circ} \mathrm{C}$ and (2) $85^{\circ} \mathrm{C}$ for $20 \mathrm{~min}$, and at $90^{\circ} \mathrm{C}$ for $20 \mathrm{~min}$; with (a) and without (b) 2mercaptoethanol. 
According to the SDS-PAGE (Fig.3) and the results of the comparative densitometric analysis (Fig.4), most of the soluble co-aggregates are the result of the disulfide interactions. Namely, after the use of 2-mercaptoethanol, the most intensive bands of co-aggregates (141 kDa and $71 \mathrm{kDa}$-bands, Fig.3, Fig.4.1) have disappeared almost completely. As a result of the degradation of co-aggregates with 2-mercaptoethanol, the content of $\beta$ - Lg and $\alpha-\mathrm{La}$ soluble forms have increased to $16.23 \%-20.5 \%$ and $7.55-9.81 \%$, respectively. Furthermore, it is obvious that solubility of $\kappa$-casein also increased. Thus, it could be concluded that these interactions occurred between the denatured molecules of $\kappa$ casein, $\beta-\operatorname{Lg}$ and $\alpha-\mathrm{La}$. Corredig and Dalgleish [18] demonstrated that the extent of the interaction of whey proteins and the raw milk casein micelles increased in time and with the temperature of heating, at temperatures between $75^{\circ} \mathrm{C}$ and $90^{\circ} \mathrm{C}$, while the amount of associated $\alpha$-La increased between $80^{\circ} \mathrm{C}$ and $110^{\circ} \mathrm{C}$. Contrarily, in the case of reconstituted skim milk, a high participation of $\alpha$-La in soluble co-aggregates was obtained even at $75^{\circ} \mathrm{C}(7.55 \%)$. This may imply that most of $\alpha$-lactalbumin of skim milk has previously been denatured.

According to our results, besides the disulfide interactions, other protein interactions are involved in co-aggregate formation. As one can see, the fractions of 64 and $57 \mathrm{kDa}$ (indicated in fig. 3. with an arrows) exist in all heat-treated samples, even after the treatment with 2-mercaptoethanol. Their presence even after reducing reagent reacting indicates that the other types of interactions are involved in their formation. This observation is in agreement with the results of Anema and Li [11].

\subsection{Influence of the addition of demineralized whey on the soluble protein composition}

The addition of demineralized whey to the reconstituted skim milk had different effects on the soluble protein composition, as shown in Figures 5-7. At lower temperature $\left(75^{\circ} \mathrm{C}\right)$, the addition of DW in concentration of $0.5 \%$ has caused the increase of the soluble aggregates content as well as the increase of the individual whey protein content (Fig. 5b). Further increase of DW content (1.0\%-2.0\%) has promoted the interaction between proteins and the formation of the insoluble co-aggregates. 


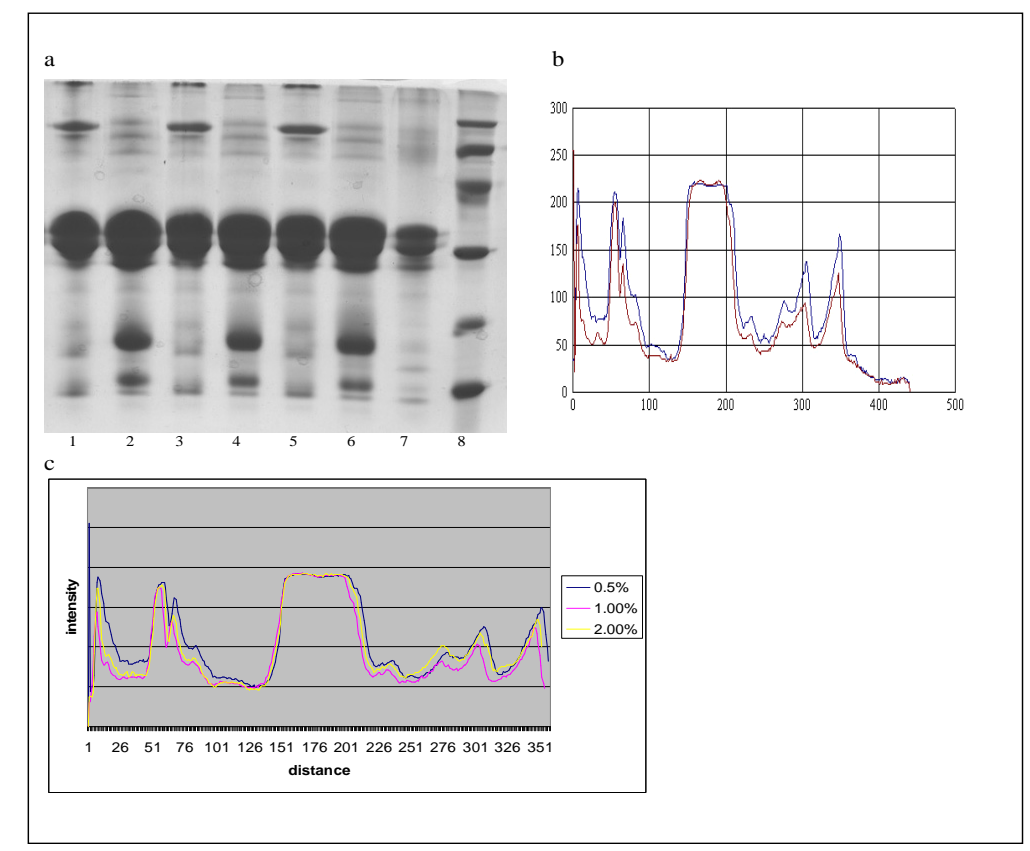

Figure 5: The electrophoretic* and comparative densitometric analysis of the reconstituted skim milk with demineralized whey added, treated at $75^{\circ} \mathrm{C}$ for 20 minutes. a. The electrophoretic analysis of the reconstituted milk with $0.5 \%(1,2), 1.0 \%(3,4)$, and $2.0 \%(5,6)$ of demineralized whey added; Nacaseinate (7) and molecular weight standards (8). b. The comparative densitometric analysis of the heat treated samples without (-) and with (-) $0.5 \%$ of demineralized whey. c. The comparative densitometric analysis of samples treated with $0.5 \%, 1 \%$ and $2.0 \%$ of the demineralized whey added.

*1, 3, 5 samples without 2-mercaptoethanol, and 2, 4, 6 samples with 2-mercaptoethanol.

As shown in Figures 6 and 7, higher temperatures $\left(85^{\circ} \mathrm{C}, 90^{\circ} \mathrm{C}\right)$ promote the formation of the insoluble high molecular weight co-aggregates. Thus, the electrophoretic patterns of samples treated at $85^{\circ} \mathrm{C}$, with and without DW added, are almost identical (Fig.6), whereas the patterns of samples treated at $90^{\circ} \mathrm{C}$ show the decrease of $\alpha-\mathrm{La}, \beta-\mathrm{Lg}$ and the soluble aggregates content. The insoluble high molecular aggregates are mostly formed during further interaction between the soluble aggregates and whey proteins, as well as through the interaction between whey proteins added. 


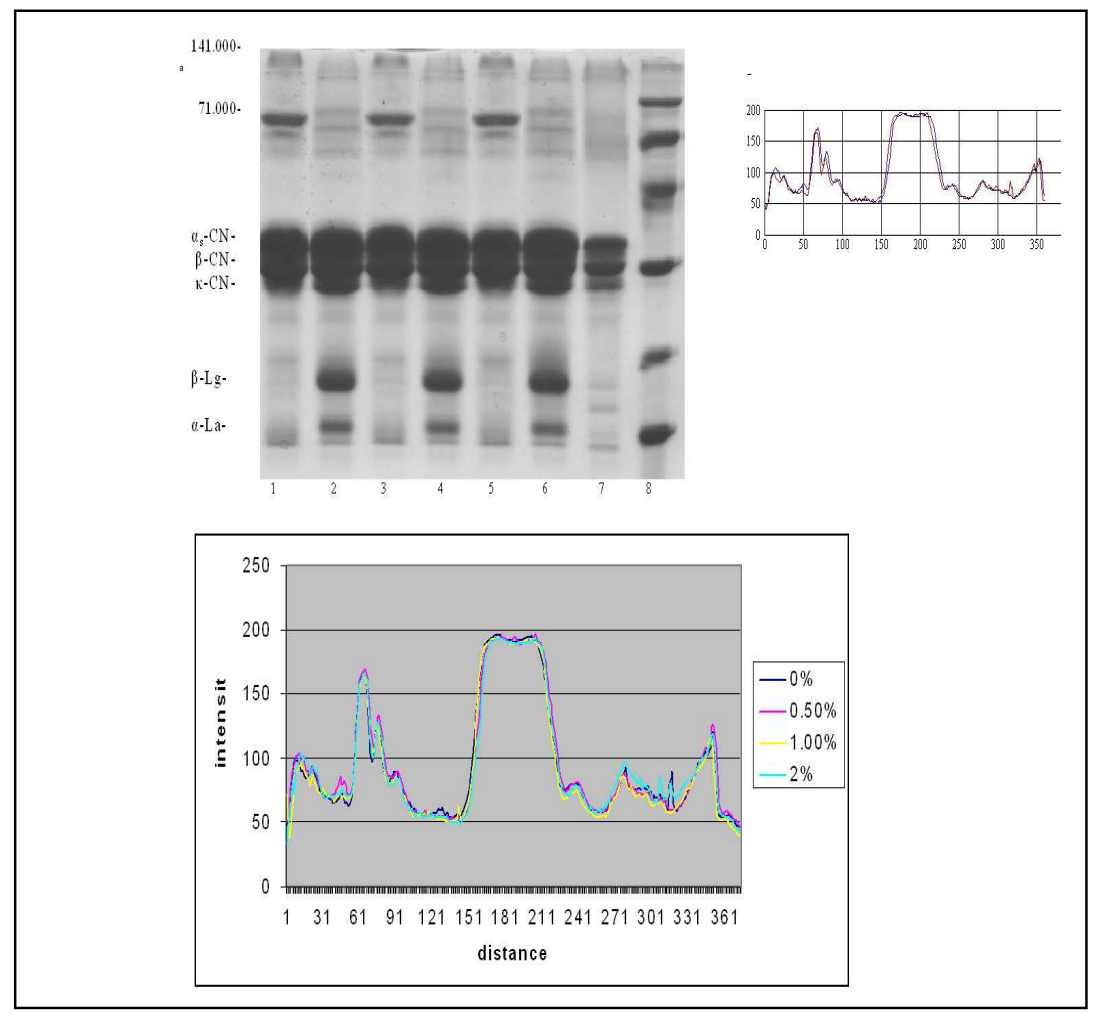

Figure 6. The electrophoretic* and comparative densitometric analysis of the reconstituted skim milk with demineralized whey added, treated at $85{ }^{\circ} \mathrm{C}$ for 20 minutes. a. The electrophoretic analysis of the reconstituted milk with $0.5 \%(1,2), 1.0 \%(3,4)$, and $2.0 \%(5,6)$ of demineralized whey added; Nacaseinate (7) and molecular weight standards (8). b. The comparative densitometric analysis of the heat treated samples, treated without (-) and with (-) $0.5 \%$ of the demineralized whey c. Comparative densitometric analysis of the samples treated with $0 \%, 0.5 \%, 1 \%$ and $2.0 \%$ of the demineralized whey added.

*1, 3, 5 samples without 2-mercaptoethanol, and 2, 4, 6 samples with 2-mercaptoethanol. 


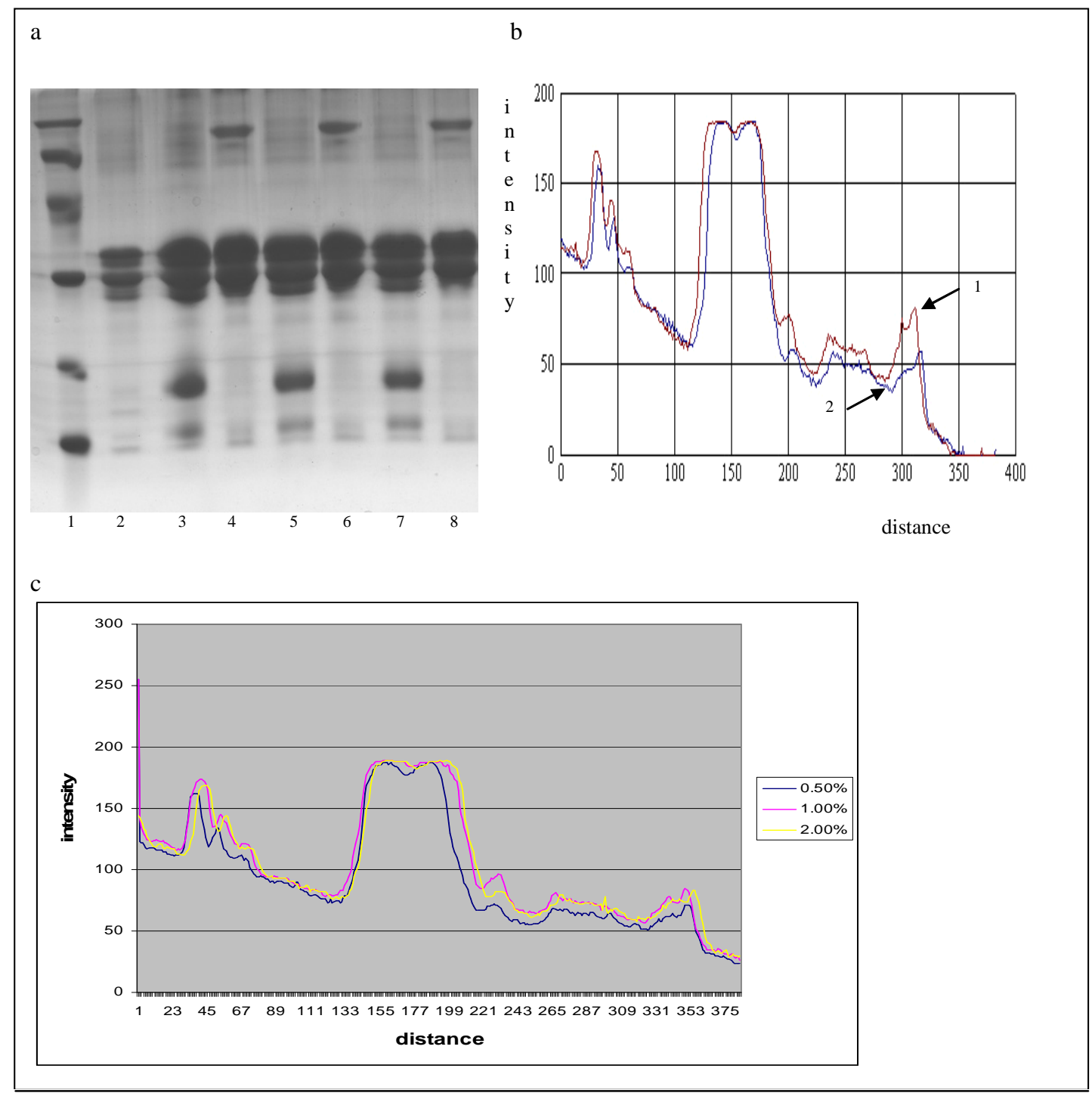

Figure 7. The electrophoretic* and the comparative densitometric analysis of the reconstituted skim milk with the demineralized whey added, treated at $90{ }^{\circ} \mathrm{C}$ for 20 minutes. a. The electrophoretic analysis of the reconstituted milk with $0.5 \%(7,8), 1.0 \%(5,6)$, and $2.0 \%(3,4)$ of demineralized whey added; molecular weight standards (1) and Na-caseinate (2). b. The comparative densitometric analysis of the heat treated samples, treated without (-) and with (-) $0.5 \%$ of the demineralized whey. c. The comparative densitometric analysis of the samples treated with $0.5 \%, 1 \%$ and $2.0 \%$ of the demineralized whey added.

*4, 6, 8- samples without 2-mercaptoethanol, and 3, 5, 7- samples with 2-mercaptoethanol.

\section{Conclusion}

According to the investigation of the heat treated reconstituted skim milk, it can be concluded that several changes take place during heat treatment. The SDS-PAGE has clearly showed that heat treatments induce the interactions between the major milk proteins and also the formation of co- 
aggregates. Co-aggregates formed during heat treatments are mostly the result of the disulfide interaction among $\kappa$-casein, $\beta$-lactoglobulin and $\alpha$-lactalbumin. Besides, other types of interactions also are involved in their formation. The level of coaggregates formation, as well as their composition, is determined by the temperature degree and the skim milk previous treatment. The adding of the demineralized whey has different effects on the soluble protein content and the composition.

\section{Acknowledgements}

This investigation has been supported by the Ministry of Science and Environmental Protection of Serbia.

\section{References}

1. Singh, H.; Waungana, A. Influence of heat treatment of milk on cheesemaking properties, Int.Dairy J. 2001, 11, 543-551.

2. Macej, O.; Jovanovic, S.; Denin Djurdjevic, J. The influence of high temperature on milk proteins. Chem. Industry 2002, 56,123-132.

3. Macej, O.; Jovanovic, S.; Seratlic, S.; Barac, M. Production of fresh chese with milk protein coagregates. Biotechnology in Animal Husbandry 2004, 20, 119-131.

4. Fox, P. F.; McSweeney, P.L.H. Milk proteins. In Dairy Chemistry and Biochemistry, 1998, Chapman \& Hall, London. pp 146-239.

5. Jollès, P.; Fiat, A. M. The carbohydrate portions of milk glycoproteins. J. Dairy Res. 1979, 46 (2), 187-191.

6. Donovan, M.; Mulvihill, D. M. Thermal denaturation and aggregation of whey proteins. Irish J. Food Sci. Techn. 1987, 11, 87-100.

7. Morr, C.V. Functionality of heated milk proteins in dairy and related foods J. Dairy Sci. 1985, 68 (10), 2773-2781.

8. Corredig, M.; Dalgleish, D. G. Effect of different heat treatments on the strong binding interactions between whey proteins and milk fat globules in whole milk. J. Dairy Res. 1996, 63 (3), 441-449.

9. Mottar, J.; Bassier, A.; Joniau, M.; Baert, J. Effect of heat-induced association of whey proteins and casein micelles on yogurt texture. J. Dairy Sci. 1989, 72 (9), 2247-2256.

10. Maćej, O. D.; Jovanović, S. T. Formation of complex between casein and whey proteins in heat-treated milk. Acta Periodica 2000, 31, 83-93.

11. Anema, S. G.; Lie, Y. Association of denatured whey proteins with casein micelles in heated reconstituted skim milk and its effect on casein micelle size, J. Dairy Res. 2003, 70, 73-80.

12. Bradford M. M. A rapid and sensitive method for quantization of microgram quantities of protein utilizing the principle of protein-dye-binding. Anal Biochem. 1976, 72, 248-254.

13. Fling, S. P.; Gregerson, D. S. Peptide and protein molecular weight determination by electrophoresis using a high-molarity Tris buffer system without urea. Anal. Biochem. 1986, 155, 83-88.

14. Jovanovic, S.; Barac, M.; Macej, O.; Denin Djurdjevic, J. Page analysis of milk proteins altered by high thermal treatment. Acta Alimentaria 2005, 34, 105-112. 
15. Corredig, M., Dalgleish, D.G. The mechanisms of heat-induced interactions of whey proteins with casein micelles in milk. Int. Dairy J. 1999, 9, 233-236.

(C) 2007 by MDPI (http://www.mdpi.org). Reproduction is permitted for noncommercial purposes. 